\title{
WRITING AS READING ITSELF: A DERRIDEAN READING OF LOST IN THE FUNHOUSE
}

\author{
Metin Boşnak \\ International University of Sarajevo, Bosnia and Herzegovina \\ Asena Boşnak \\ Heidelberg University, Germany
}

\begin{abstract}
Lost in the Funhouse is like textbook illustration of Derrida's views on language and writing. The book is both a guide for "how not to write" and "how not to define" writing, thus defying an ultimate center. Although the lack of a "proper" theme and heavy metafictional structure makes it "difficult to read", it is a struggle to subvert the definitions of writing. The author deconstructs the conventional form and theme that is believed to be necessary for writing. In this respect, Barth operates through the narratives like Derrida moves through ideas in history, and ending up with the conclusion that interplay is what matters rather than a fixed meaning.
\end{abstract}

Keywords: Derrida; Deconstruction; Lost in the Funhouse; Barth; Theory of Language and Difference 
Theory of language and writing in particular has proved to be a fundamental issue in modern times probably because communication at technical, diplomatic, philosophical levels has gained importance. Many of the modern ideas about writing, as about other issues, can certainly be traced back to Plato. Somehow, Plato has constructed a great system of thought, which philosophers inevitably have argued for and against to come up with a system of their own. In other words, though Plato has also synthesized ideas that were in the air before him, his system appears to encompass classical, modern and even post-modern ideas, and writing being one of them.

Plato provides a background of mediocrity even today against which people argue as far as writing is concerned. It was a common idea from Plato to Saussure that writing functions as a documentation of speech, a substitute for it in its absence. As speech has been seen as derivative of the thought, writing, similarly, has been seen as doubly derivative. Along with its secondary value to speech, writing's materiality by itself was completely ignored, since it was only a representation of representation, which is reminiscent of Platonic concept of world of ideas. Saussure, for instance, believes the distinctiveness of language and writing systems, stating that the latter exists for the representing the former (Saussure, 1959, p. 23). He believes that there is an oral tradition independent from writing; hence, "purity" of speech is possible (Ibid., p. 24).

The privileging of writing over speech was the classical understanding. However, Derrida rejects this hierarchy, noting that saying and hearing do not always correspond to each other, and that the speech is derivative. A term coined by Derrida, difference, meaning "to defer", and homophone of the word difference meaning, "todiffer" illustrates this problem. Derrida asserts that it is not possible to distinguish the two words in speech; therefore, Saussure's attempt to restrict the language to audible word is completely rejected. Therefore, his philosophy of writing undermines the Platonic one and those who agreed with Plato.

In his essay, entitled "Différance" Derrida indicates that the signified always traces to different 'signifieds' while meaning is postponed each time through the constant deferral, which results in an endless chain of signifiers. According to him, there is no linear development and semantic center that totalize and harmonize the meaning; instead, there is "interplay ad infinitum" and "systematic play of differences.”Derrida rejects the logocentric sign systems completely. He believes that in the beginning, "man" was the center of the systems and orientation was towards the "humanity." However, after a certain philosophical event, man ceased to be the center of the world, and everything is left to decentralization, giving way 
to free play (Derrida, 1978, p. 278). Without a center, language is structured through the differences; therefore, absolute truth is not possible.

The present paper will use Derrida's theories to show the compatibility of the theory as applied to John Barth's book, Lost in the Funhouse. Lost in the Funhouse is a post-structuralist short story collection, consisting of a maze of stories, in which the author forces the reader to get lost with him. In that sense, the book works like a textbook illustration of Derridean philosophy. In the book, the language's documentary function is completely disregarded. There only remains a Funhouse consisting in a series of the floating signifiers.

Tony Tanner suggests that in Barth's works, signs "become more important than their referents" and that he "plays with them in such a way that any established notions of the relationship between word and world are lost or called into doubt" (Tanner, 1974, p. 240). As Derrida suggests, writing's function is not to transfer sounds into written words, it is a material by itself that functions in the signifying process. Likely, in his work, Barth does not provide a reflection of the real world. Apart from this, he constantly reminds the reader that this fiction is a maze of words and that the signification is an endless process. With his unconventional book, he forces the reader to understand that the world and literature are not necessarily one, and in fact, the reader is called in sometimes to write the text.

With the use of metafiction, it is shown in the Lost in the Funhouse that language does not function to represent the world; it functions to prove that it has nothing to do with reality. By drawing attention to the language, the book prevents the reader from getting into the realm of the stories. The text is only a playground; it does not necessarily take the reader, author or narrator to anywhere. It wants to get readers lost in this playground, and indeed enjoy getting lost in this process by undermining the desire to reach a final point.

As has been mentioned above, Derrida (1981) states that language consists of "systematic play of differences," indicating that the sign is not the representation for meaning and that signifying process is a constant difference and deferral of signifiers instead of a final signified. The meaning is an endless game of tracing and it is

constituted by a tissue of differences, in the extent to which there is already a text, a network of textual referrals to other texts, a textual transformation in which each allegedly "simple term" is marked by the trace of another term, the presumed interiority of meaning is already worked upon by 
its own exteriority. It always already carried outside itself. It already differs (from itself) before any act of expression (Ibid., p. 33).

This is where intertextuality is come into being: it is the end of the linear structure and the birth of the interwovenness of the texts. Lost in the Funhouse is a good example of intertextuality, decentering and language as material rather than a teleological end. The book starts with "Frame Tale" a Mobius strip that suggests, "Once upon a time there was a story that began." Each turn of the Mobius strip is a retelling of the same story that has already been told. Although it says the same thing, it indicates that it renews itself each time. In his work, The Play of the Double in Postmodern American Fiction, Gordon Slethaug depicts the frame tell as follows:

\begin{abstract}
Illustrat[ing] precisely Derrida's view to identify the structurality of structure, whether in myth, literary form, or idea is thereafter to deny the desire for thematic center or presence. Space encircled by the Möbius strip is a nonlocus, a hole, a loss, the absence of a center or subject, a labyrinth, a universe of discourse where an infinite number of sign substitutions come into discourse where an infinite number of sign substitutions come into play, where nothing contains everything, and where a gap constitutes the subject (Slethaug, 1993, p. 138).
\end{abstract}

This depiction of a Möbius strip seems to reflect endlessness of signifiers Derrida has suggested. Here, the Möbius strip is not a geometrical shape; it is a symbol of a theory, a symbol that is not absolute in the sense of stability. This shape is crafted out of the material of language; it is not a linear shape but in encloses the texts creating a new start for its each turn. It is both closed and endless. It is an intertext, a combination of the different tissues of all the texts that has been written. Along with its intertextuality, it contains endless possibilities.

Also in the title story, the narrator Ambrose is in a funhouse where he encounters many images of himself reflected on the mirrors; however, there is no center, there is no "ultimate" image of himself that he can rely on. This frustration makes him unable to find a way out of the plight. He feels like "an odd detachment, as though someone else were the Master" (Barth, 1988, p. 81). The signifieds that he believes to own are lost since they give way to endless possibilities. Throughout the story, the narrator interrupts the narrative reminding that the story is not reaching a final point. For instance he says, "There's no point in going farther; this isn't going 
anywhere; they haven't even come to the funhouse yet." In his story, Barth "risks meaning nothing." Likewise, Derrida (1981) states: "To risk meaning nothing is to start to play, and first to enter into the play of différance which prevents any word, any concept, any major enunciation from coming to summarize and to govern from the theological presence of a center the movement and textual spacing of differences" (p. 14). In his book Derrida and Lacan: Another Writing, Michael Lewis, explains that:

The process of differentiating is the inscription of traces of the absence of one signifier in and as the presence of another. It is the process of archi-writing or archi-tracing. This will turn out to be all that we can know of that which is beyond language, that which is 'real': a mere (ability to) trace. Derrida is quite explicit that the 'trace' is the 'remnant', the slightest vestige of the real, which is (potentially) a much greater and stranger entity, with many more capacities (Lewis, 2008, p. 118).

While the author "survives through", trace he is also "effaced" through it (Dick and Wolfreys, 2013, p. 52). Ambrose, can only survive by writing: "This is what they call 'passion.' I am experiencing it" (Barth, 1988, p. 84). However, this trace does not make him present in the text: "How readily [Ambrose] deceived himself into supposing he was a person" (Ibid., p. 93). Ambrose is both present and absent in the text. The narrator says: "Is there really such a person as Ambrose[?]"

Lost in the Funhouse is a self-reflexive novel that does not seek verisimilitude. The author constantly reminds himself to the reader, reveals the figures of speech and narrative techniques used in a way that turning clichés and used-upness into a story about story telling. Barth's stories "constitutes a world unto itself, operating under laws of its own making” (Green, 1991, p. 229-242). The story of Echo's linguistic structure is a good example:

One does well to speak in the third person, the seer advises, in the manner of Theban Tiresias. A cure for selfabsorption is saturation: telling the story over as though it were another's until like a much-repeated word it loses sense... Tiresias the prophet. What is he doing here? Conversing with Narcissus. How does he know-because he knows everything. ... Tiresias can't espy the unseeable, one may yet distinguish narrator from narrative, medium from message. ... Considerable time has elapsed, it seems, 
since seer and seeker, prophet and lost, first met in the cave (Barth, 1988, p. 98-102).

It may be taking the life as a "raw material" but in Richard Poiriers words, it transforms language into a "world elsewhere" (Quoted in Green, 1991, p. 229-242). Language becomes a new world by itself. John Barth does not seek to convert the experience into a narrative, his effort is to create fiction world that is independent from reality. John Barth suspects that signifiers are able to represent the world and he believes that the playfulness of the words creates its own creative realm.

Lost in the Funhouse dismisses the fear that fiction is not able to reflect fully, because it is not its objective in the first place. John Barth interrupts the regularity of sentence pattern to break the myth of realism. He makes fun of the effort that aims to achieve realistic fiction and makes use of this as a subject. The stories are about "the possibility of humanizing play of language" (Ibid.). It is like fictionalizing the Différance process; making a story out of the endlessness of signifiers. This process itself emphasizes the value of form and language "for its own sake" (Ibid.). This technique is frequently used in the title story:

En route to Ocean City he sat in the back seat of the family car with his brother Peter, age fifteen, and Magda G - ' age fourteen, a pretty girl and exquisite young lady, who lived not far from them on B - Street in the town of D -, Maryland. Initials, blanks, or both were often substituted for proper names in nineteenth-century fiction to enhance the illusion of reality. It is as if the author felt it necessary to delete the names for reasons of tact or legal liability. Interestingly, as with other aspects of realism, it is an illusion that is being enhanced, by purely artificial means. Is it likely, does it violate the principle of verisimilitude, that a thirteen-yearold boy could make such a sophisticated observation? A girl of fourteen is the psychological coeval of a boy of fifteen or sixteen; a thirteen-year-old boy, therefore, even one precocious in some other respects, might be three years her emotional junior.

John Barth suggests that "owing to the floating nature of language, meanings are untenable" (Tsai, 2003, p. 37-62). In Lost in the Funhouse, attempts for realistic depiction are frequently presented as problematic. For instance, in the book it goes: "To say that Ambrose's and Peter's mother was pretty is to accomplish nothing; 
the reader may acknowledge the preposition, but his imagination is not engaged. Besides, Magda was also pretty, yet in an altogether different way" (Barth, 1988, p. 75). His half way depictions like "the brown hair on Ambrose's mother's forearms gleamed in the sun like" and "the smell of Uncle Karl's cigar smoke reminded of" (ibid, p. 74) indicate that the effort for achieving verisimilitude is vain.

Barth's concerns are not only about the techniques used to achieve verisimilitude. He thinks "floating nature of language" also results from the lack of correspondence between the sign and the signified. As Derrida indicates, the signs only mean in relation to each other by differing and deferring; there is no absolute meaning of the signifiers. Likewise, Ambrose experiences this problem: "It was to be my fate to wonder at that moniker, relish it and revile it, ignore it, stare it out of countenance into hieroglyph and gibber, and come finally if not to embrace at least accept it with the cold neutrality of self-recognition ... Knowing well that I and my sign are neither one nor quite two." Derrida has a similar saying: "I love this name [Derrida], which is not mine of course (Branningan and Robbins, 1996, p. 219).

Moreover, just as Derrida does, the book lays bare the problem of speech's authority over writing. The story "Petition" illustrates the difference between life and language. In the story, there are Siamese twins, and the one attached on the backside writes a petition to the King to help him to get detached from his brother:

I am slight, my brother is gross. He's incoherent but vocal. I'm articulate and mute. He's ignorant but full of guile; I think I may call myself reasonably educated, and if ingenuous, no more so I hope than the run of scholars. My brother is gregarious: he deals with the public; earns and spends our income ... For my part, I am by nature withdrawn, even solitary: an observer of life, a meditator, a taker of notes, and a dreamer if you will (Barth, 1988, p. 62).

The Siamese twins, metaphorically refers to the written and oral manifestation of the language. Tony Tanner interprets that the "incoherent brother is like life itself, constantly shrugging off the attempts of language to circumscribe it within particular definitions. Language, in the form of the articulate brother, would be happy to pursue its inclination to ponder its elegant patterning in pure detachment from the soiling contacts of reality" (Tanner, 1974, p. 254). Such a distinction between life and language implicit in the relationship between the two brothers seems to correspond to Derrida's comparison between "speech" and "writing" (Green, 1991, p. 229-242). 
In Derrida's thoughts, writing has been viewed as "clambering pick-a-back on the more authentic use of language" while speech [is seen as] language in action (Ibid.). The incoherent brother experiences life, he even has an intercourse with the other brother's love, Thalia, while the petitioner brother follows him and experience everything secondarily only by watching. The correspondent in "Petition" must follow after his more active brother the speech as it has been dictated. However, the petitioner believes he has an advantage. "I can see him without seeing me; can therefore study and examine our bond, however to dissolve it, and take certain surreptitious measures to that end, such as writing this petition. Futile perhaps; desperate certainly" (Barth, 1988, p. 63). Writing contains the speech; however, it is not dependent on it. It has a world by itself. Writing is not dependent on speech; speech is dependent on writing to stay alive. According to Green (1991), Barth's story dramatizes Derrida's characterization of writing as separate and secondary, but, through its very existence as a work of literary art ... it also overcomes the specious opposition of speech and writing. Language in "Petition serves as both "elegant patterning" and direct expression, an affirmation of both art and "life." More importantly, the need to affirm imaginative writing in this way--to overcome the "fear" so well represented by the story's protagonist--becomes the true subject of the story (p. 229-242).

As the forgoing has shown, Lost in the Funhouse is like textbook illustration of Derrida's views on language and writing. The book is both a guide for "how not to write" and "how not to define" writing, thus defying an ultimate center. Although the lack of a "proper" theme and heavy metafictional structure makes it "difficult to read", it is a struggle to subvert the definitions of writing. He deconstructs the conventional form and theme that is believed to be necessary for writing. In this respect, Barth operates through the narratives like Derrida moves through ideas in history, and ending up with the conclusion that interplay is what matters rather than a fixed meaning.

\section{References}

Barth, John. 1988. Lost in the Funhouse: Fiction for Print, Tape, Live Voice.

Doubleday Anchor ed. New York: Anchor Press.

Brannigan, John, and Robbins. Ruth. 1996. As If I Were Dead: AN Interview with Jacques Derrida, in Applying: to Derrida. London: Macmillan.

Daniella, Maria-Dick and Julian Wolfreys. 2013. The Derrida Wordbook. Edinburgh:

Edinburgh University Press. http://www.questia.com/read/122585309.

Derrida, Jacques. 1978. Writing and Difference. Chicago: University of Chicago Press. 
Derrida, Jacques, and Alan Bass. 1981. Positions. Chicago: University of Chicago Press.

Green, Daniel. 1991. "Metafiction and Romance." Studies in American Fiction. 19, no. 2: 229-242. http://muse.jhu.edu/ (accessed July 28, 2014).

Lewis, Michael. 2008. Derrida and Lacan: Another Writing. Edinburgh: Edinburgh University Press. http://www.questia.com/read/117301906.

Saussure, Ferdinand De. 1959. Course in General Linguistics. New York: Philosophical Library.

Slethaug, Gordon E. 1993. The Play of the Double in Postmodern American Fiction. Carbondale, IL: Southern Illinois University Press. http://www.questia. $\mathrm{com} / \mathrm{read} / 7280340$.

Tanner, Tony. 1974. City of Words: American Fiction 1950-70. New York: Harper \& UP.

Tsai, Chia-chin. 2003. "Rupture/Rapture in the Funhouse: On John Barth's Lost in the Funhouse." Journal of Applied Foreign Languages 1, no., pp. 37-62. http://repository.nkfust.edu.tw/retrieve/18921/JAFL_V01_06_Abstract.pdf. 